Journal of Economics and Behavioral Studies

Vol. 4, No. 1, pp. 26-33, Jan 2012 (ISSN: 2220-6140)

\title{
The Role of FDI on Stock Market Development: The Case of Pakistan
}

\author{
*Ali Raza, Nasir Iqbal, Zeshan Ahmed, Mohammad Ahmed, Tanvir Ahmed \\ Hailey College Of commerce, PU Lahore, Pakistan \\ *aliraza_ghuman01@yahoo.com
}

\begin{abstract}
The purpose of this study is to empirically analyze the role of foreign direct investment in developing host country's stock markets and to examine whether they are related or not. The key interest turns around the admiring role of FDI in Stock market development of Pakistan. Our work also aims to investigate the effect of foreign direct investment along with domestic savings, exchange rate and inflation in developing Pakistan stock markets in a rapidly changing political environment. This study applies Ordinary Least Square (OLS) method of regression by using annual time series data for the period 1988-2009 in case of Pakistan to estimate empirical relationships among variables. The results disclose a positive impact of foreign direct investment along with other explanatory variables in developing Stock markets of Pakistan. The study findings can be used to help government policy makers to encourage FDI and take various steps to provide incentives and save foreign investors interest in a volatile political environment that prevailing in the country. Adequate facility of infrastructure can enhance FDI. The volatility of exchange rate and inflation rate should also be minimized through monitory policy while domestic savings must also be encouraged in the country through appropriate and encouraging saving policies. Our effort exclusively study development of Stock markets in Pakistan with special reference to foreign direct investment and other variables. Our study depicts a closer relationship between FDI and Stock Market Development.
\end{abstract}

Keywords: Stock Market Development, FDI, Exchange Rate, Domestic Savings, Inflation Rate, Pakistan

\section{Introduction}

A very important and integral part of a country's financial system is the stock market and a strong financial system guarantees the financial development and growth of that country. A well organized and managed stock market encourage investment by identifying and supporting that productive projects that will ultimately lead to economic development .The stock markets are the best indicators to estimate future economic activity and stock market health is also a measure of economic strength of a country .In order to boost economic development of a country the development of stock market is vital. The Islamic Republic of Pakistan is a country situated at an intersection of three major counties of Asia. It is a developing, lower middle-income country with GDP per capita $\$ 2500$, and have a population of 187 million. The Karachi stock exchange (KSE) is the oldest stock exchange of Pakistan established in 1947.

The other stock exchanges of the country include Lahore stock exchange (LSE) and Islamabad stock exchange (ISE) established in 1974 and 1997 respectively. According to a recent survey, about 80 to 85 percent of turnover occurs at KSE with average daily turnover of 145 million shares. Figure 1 shows an increasing trend in stock market capitalization for the year 2001 to 2007, all this due to stability in political and economic sector. However, the growth slows down after 2007. However, with the help of standby agreement with IMF in 2008, the country's foreign reserves increased and current account stabilizes. According to a report released in 2011 by the World Bank the market capitalization of listed companies in Pakistan increased to $\$ 38168586546$ in 2010.Given the importance of Stock markets and its downward trend over the last few years this study also attempts to examine the factors that also affects stock market capitalization in Pakistan.

A major source of investment inflow for a developing country is foreign direct investment. FDI provides a passage for technology, managerial skills, and human capital to come into the host country. However, literature shows a mixed behavior of FDI in economic development. The theoretical work shows a positive impact of stock market performance on economic growth (Rahman \& Salahuddin, 2009; Mohtadi \& Agarwal, 2001; Agarwal, 2001. Nieuwerburgh, Buelens \& Cuyvers (2005) research gives us very strong positive 
evidence that the stock market development produced economic growth in a country. The capital market development is correlated with economic growth and financial development will result in economic growth (Brasoveanu, Dragota, Catarama \& Semenescu, 2008).

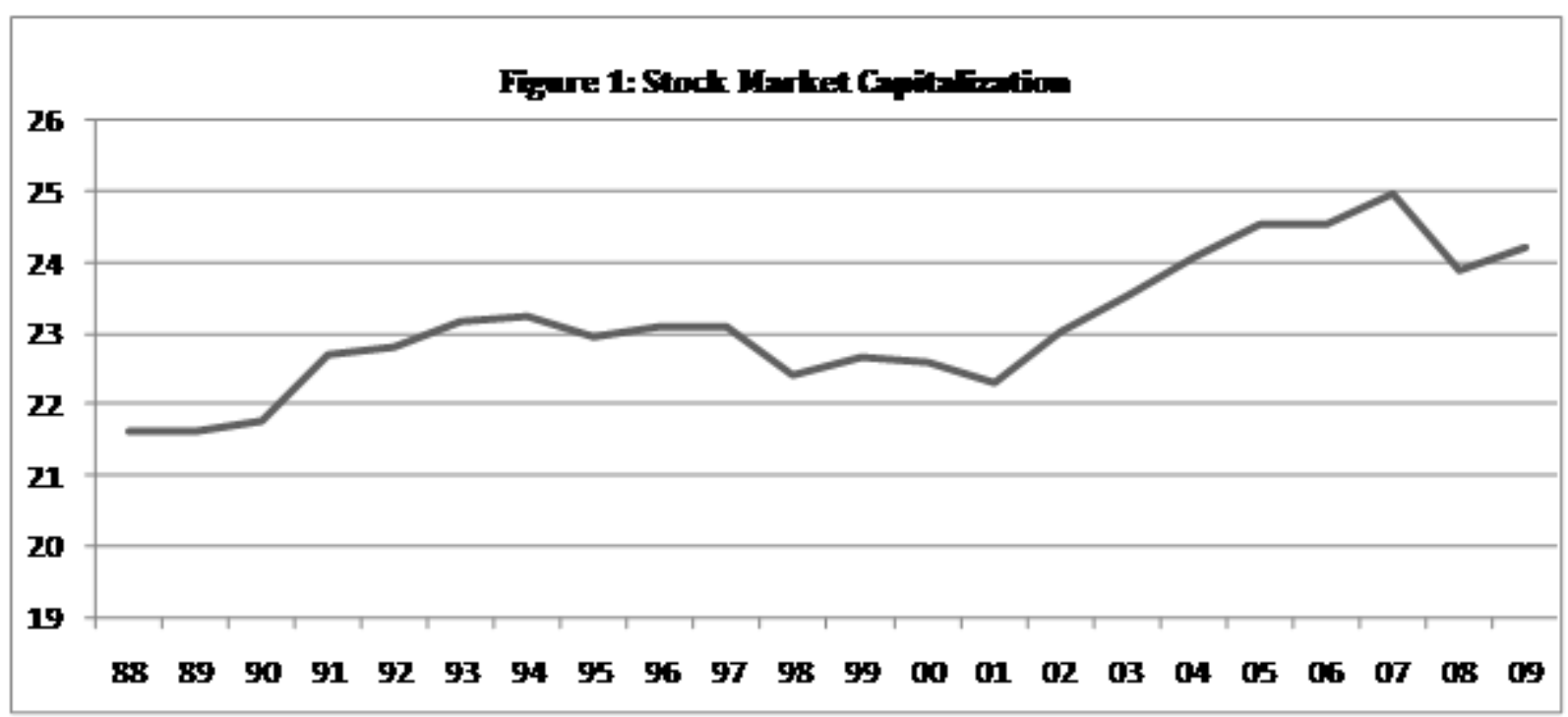

Source: World Development Indicators (2009)

According to Alfaro (2003), FDI in primary sector of the economy can have a negative effect on economic growth whereas there is a positive relationship when investment is made in manufacturing sector. However, FDI contributes positively to economic growth but its overall impact on economic growth may not be important and the constituents of FDI made a positive contribution (Ayanwale, 2007). Countries that have well established financial markets can achieve a lot more from FDI (Alfaro, Chanda, Ozcan \& Sayek, 2004). In developing economies except developed economies, FDI inflow can have a positive impact over economic growth (Johnson, 2005). In Nigerian experience, the FDI and financial development can made a negative impact over the economic growth but the liquidity of financial market can be a source for economic growth (Saibu, Wosa \&Agbeluyi, 2011). However, some studies show that FDI does not have a direct influence over economic growth (Carkovic and Levine, 2002). Therefore, the theories yield ambiguous expectations about the growth effects of FDI. Adam and Tweneboah (2009) argued that there is a three-sided causal relationship between FDI and stock market development (I) FDI stimulates economic growth (II) Economic growth stimulates stock market development (III) So we make inference that FDI promotes stock market development. Due to the given background information the major aim of our study is to identify the major contributing factor to development of Pakistan stock markets with our particular emphasis on FDI and to identify the relationship between Stock market development, FDI, Domestic savings, Exchange rate, and Inflation rate in Pakistan using ordinary least square method over the period 1988-2009. The balance of paper organized as follows. Section 2 provides us a brief overview of literature. In section 3 outlines Methodology and the estimable model with data collection method. Section 4 discusses empirical findings. In final section 5, we present our study conclusion with some policy implications.

\section{Literature Review}

Over the last two decades the financial markets of developing countries shows a graph with an increasing trend especially in the Stock markets. A well-managed stock market attracts foreign investments in the country. The studies in "economics literature" show a positive relation between FDI and Stock market development. Claessens, Klingebiel, \& Schmukler (2001) try to investigate whether the foreign direct investment is an alternate of stock market development in countries that are more risky and financially underdeveloped or whether the FDI is seen as something else more attractive only to overcome the barriers of investment through capital market. By using the eight variable models from year 1975 to 1999 and by applying regression technique they found a strong positive relationship between foreign direct investment 
and stock market development. Adam and Tweneboah (2009) work shows how FDI impact stock market development in Ghana by using the co integration technique that was introduced by Engle and Granger in 1987 the results shows a long run and positive relationship between FDI, Nominal exchange rate and Stock Market Development. Nazir, Nawaz \& Gilani (2010) try to find the relationship between stock market development and FDI through economic growth for the year 1985 to 2008 and shows significant positive relationship between FDI and growth of economy. Torre, Gozzi \& Schmukler (2006) argues that the reforms in a country in shape of privatization, supervisory improvements etc. results in improvement of its Stock markets. Kalim \& Shahbaz (2009), Baker, Foley \& Wurgler (2004), Halalmeh \& Sayah (2010) also found the positive impact of FDI on stock market development.

Domestic savings in a country also contributes to stock market development of that country because with an increase in saving rate more idle money is available to people to invest so they make investment in the Stock markets and due to this fact of savings more capital money is flowing through the stock markets. Yartey (2008) use a panel of 42 emerging economies of the world for the year 1990 to 2004 to show Macroeconomic determinants of Stock Market and found the positive impact of gross domestic savings on stock market development. Naceur, Ghazouani, \& Omran (2007) argue that economic growth is accelerated by financial development and financial development will ultimately increase savings rate. They conduct an empirical study by using a panel of 12 North African and Middle East countries and show that saving rate is a determinant of Stock market development. Liu \& Garcia (1999) argues that the low or smaller stock markets in Latin American countries are the result of low saving rate in those countries. Whereas the East Asian countries have better position of their Stock markets due to usual high savings rate. Kalim \& Shahbaz (2009) found statistically positive strong relationship between savings rate and Stock market development.

The Macroeconomic stability of the country is an important determinant for development of the stock market and it plays a major role in attracting foreign direct investment in the country. Therefore more stable the economy of country results in more foreign investors will invest in stock markets. We use exchange rate as a measure of macroeconomic stability for a country. Tabak (2006) try to find this relationship in Brazilian economy by using unit root and co-integration tests and found no long run relationship between exchange rate and Stock market in Brazilian economy. Dimitrova (2005) focus on United Kingdom and United states for the period of 1990 to 2004 by using open economy multivariate short-term model to show a relationship between exchange rate and stock markets. The findings may reveal that the depressing stock markets may be the result of depreciating currency whereas the boosting stock markets may be the result of appreciating exchange rate of that country. Subair \& Salihu (2010) found negative impact of exchange rate on Nigerian stock markets and concluded that stock market development may only be possible by stabilizing the movement in exchange rate. Parsva \& Lean (2011) study about six Middle East countries to investigate the stock prices and exchange rate relationship by using multifactor determinants before and during 2007 global financial crises and the study results shows a mixed relationship. Adjasi \& Biekpe (2005) argued that exchange rate depreciation reduces stock market return for foreign investors so resulting in no development in stock markets. Muhammad \& Rasheed (2002) study four Asian countries and their results shows no association between stock prices and exchange rate in short run. Franck and Young (1972) using six different exchange rate found no relationships between stock market development and exchange rate.

The Inflation rate shows the rate of change in prices in the economy. Documented evidence shows that an economy's performance measures and inflation rate are negatively correlated when the inflation rate is very high enough. Boyd, Levine, \& Smith (1996 and 2001) try to study the empirical relationship between long run inflation rate and economy financial system performance. The study result shows countries with inflation rate below a critical level (average inflation below 15 percent) there is a strong negative correlation between inflation rate and performance of financial markets but an incremental increase in inflation rate in high inflation countries (Countries with average inflation rate above 15 percent) can have a minimal impact on stock market development meaning no significant relationship between inflation rate and stock market development. Ghazouani (2004) extend the work of Boyd et al to the MENA region and found that whatever the inflation rate is the minimal increase in inflation is not hurtful to the financial sector performance. Garcia and Liu (1999) found insignificant and negative impact of inflation on market capitalization and argued that macroeconomic stability does not have any impact over stock market capitalization. Naceur, Ghazouani, \& Omran (2007) found a negative and significant impact of macroeconomic stability (As inflation rate) on stock 
market capitalization. However, Kalim \& Shahbaz (2009) found a positive minimal impact of inflation on stock market development. Shahbaz, Ahmed, \& Ali (2008) also found positive association between inflation and stock market development and argued that Pakistan Stock market provides hedge against inflation so they may become the safe place for investors to invest in. The review of the above literature suggest us the role of FDI in developing stock markets of different countries in different areas of the world. Our study seeks to fill any gap in literature because in past three to four years major political and economic changes occurred in Pakistan so these changes have a very significant effect on its economy measures.

\section{Methodology}

Multiple Regressions: The overall purpose of applying multiple regressions is to know the relationship between several independent variables and a dependent variable. Let us take an example that might help us. Suppose we are interested in forecasting how much an individual enjoys their job. We might have variables as salary, Academic background, age and sex, past working experience that can help us to determine job satisfaction. If we collected data on these variables, maybe by surveying hundred members from public we will be able to see that how many and which variables can give us an accurate prediction of job satisfaction. We find that salary, past experience and type of occupation may help us to accurately predict job satisfaction. When we use multiple regressions in psychology, many of the researchers use the term "independent variables" to ascertain those variables that will influence some other "dependent variable". We also prefer to use the term "independent variables" for those variables that can help us in predicting the score on another variable that we term as "dependent variable". Thus in our above example, salary, past experience and type of occupation are significant independent variables that can allow us to estimate the dependent variable-job satisfaction.

Data and Variables: Our Study uses five variables that include Stock Market Development (SMD), Foreign Direct Investment (FDI), Domestic Savings (Sav), and Exchange Rate(ER) and Inflation rate (INF) along with their theoretical and empirical explanation. The data for Exchange Rate(ER) is obtained from Penn World Table Center for International Comparisons online from the official website of Penn World Table. This data is obtained on an annual basis from 1988 to 2009. The Data for SMD, FDI, Sav and INF is obtained from World Development Indicators Mark 5 May 2011 from the official website of the World Bank with an annual frequency from 1988 to 2009. The above-mentioned data sources have been chosen because they are the most reliable one and mostly used by every researcher. The data from World Bank have benefits that the data offers numerous arrangements tools due to this the required data can be downloaded in a direct excel file. While the weak point is that, the data available is not updated frequently.

Foreign Direct Investment (FDI): FDI is an important source of stock market Development (SMD).It can also play its role in raising domestic savings in the country through creation of job and enhancement of technology transfer (Singh, 1997). Without FDI, it would be difficult to obtain such a large capital through the country's own domestic savings. Adam\& Tweneboah (2009), Claessens, Klingebiel, \& Schmukler (2001) and Kalim \& Shahbaz (2009) found positive and statistically strong relationship between FDI and Stock Market Development (SMD). Foreign direct investment net inflows in reporting economy (current US\$) is used as proxy for FDI. We expect Positive impact of FDI on SMD.

Domestic Savings (Sav): Domestic Savings accelerate economic growth through boosting Stock market. It also increases quantity of investment and improves that investment (Yartey, 2008). Liu \& Garcia (1999) argued that larger the domestic savings in the country results in higher amount of capital inflows through the stock markets. Kalim \& Shahbaz (2009), Yartey (2008), Liu \& Garcia (1999) found a positive significant relationship between Domestic Savings and Stock Market Development. Gross domestic savings (current US\$) is used as a proxy for Domestic Savings (Sav) and we also expect positive impact of Domestic Savings (Sav) on SMD.

Exchange Rate(ER): The Stock prices and exchange rate relationship (ER) is very important because a change in exchange rate may result in also a change in Stock Market prices because when the currency of a country is weak then it less likely that the foreign investors will invest in that country due to currency risk. As due to fluctuation in currency and the risk faced by the foreign investors, we use the Pakistan Rupee-US 
Dollar exchange rate to measure the macroeconomic stability of the Pakistan. Subair \& Salihu (2010) and Dimitrova (2005) found negative impact of Exchange Rate (ER) on SMD. Exchange rate of local currency units per US\$ is used as proxy for Exchange Rate (ER). We expect negative sign of ER.

Inflation (INF): Evidence shows that the countries that have an average rate of inflation can have a welldeveloped financial sector than the countries that have a high inflation rate. Boyd, Levine, \& Smith (1996 and 2001) found a negative relationship between inflation and stock market development for countries where the Inflation rate is low to average. However, for the high inflation countries when there is additional increase in inflation the marginal impact of inflation on stock market development decreases rapidly. Ghazouani (2004) also found the similar insignificant results that the increase of inflation is not hurtful to the stock market development. The proxy used for Inflation (INF) is Inflation consumer prices (annual \%).

Econometric Model: The main objective of this study is to identify and analyze the roll of Foreign Direct Investment in Developing Stock Markets. The Hypothesis here is that the increased Foreign Direct Investment of a country like Pakistan helps in Development of Stock Markets. We use the following model in the form of equation to investigate the impact of Foreign Direct investment on Stock Market Development along with the exchange rate, Domestic Savings and Inflation rate.

$\ln (\mathrm{SMC})=\boldsymbol{\beta} 0+\boldsymbol{\beta} 1 \ln (\mathrm{FDI})+\boldsymbol{\beta} 2 \ln (\mathrm{Sav})+\boldsymbol{\beta} 3 \ln (\mathrm{ER})+\boldsymbol{\beta} 4(\mathrm{INF})+\mathrm{U}$

Where SMD $=$ Stock Market Development

FDI= Foreign Direct Investment

Sav= Domestic Savings

$\mathrm{ER}=$ Exchange Rate

$\mathrm{INF}=$ Inflation rate

Further $\beta 1, \beta 2, \beta 3$ and $\beta 4$ are the parameters of the equation that link together the Dependent variable with independent variables. These parameters represent the effect of independent variables (FDI, Sav, ER and INF) on dependent variable (SMD). In the above equation, natural log values of the variables are used to transform it into a linear equation and to facilitate the use of ordinary least square method.

\section{Results}

An ordinary least square (OLS) regression method was applied to determine the impact of Foreign Direct Investment on Stock Market Development in Pakistan. The regression results for the model are reported in table 1.

Table 1: Regression Results for FDI on Stock market Development in Pakistan ( $\mathrm{N}=22)$

\begin{tabular}{lllll}
\hline Variables & Coefficients & Std Error & t-stat & p-value \\
\hline Intercept & -17.65037 & 9.449469 & -1.87 & 0.079 \\
FDI & .6948205 & .2151036 & 3.23 & 0.005 \\
Sav & 1.356555 & .5446953 & 2.49 & 0.023 \\
ER & -1.172403 & .5817465 & -2.02 & 0.060 \\
INF & -.0325442 & .0292305 & -1.11 & 0.281
\end{tabular}

(FDI and Sav are statistically significant at 5\%)

(ER is statistically significant at 10\%)

(INF shows insignificant result)

\begin{tabular}{lrrr}
\hline R Square & Adjusted R Square & F- Probability & \multicolumn{1}{c}{ Durbin Watson Statistics } \\
\hline 0.8393 & 0.8015 & 0.000 & 1.712994 \\
\hline
\end{tabular}


Work has been done in this paper to recognize macroeconomic variables with certain emphasize on FDI affecting stock market development of Pakistan. Twenty-two years data was collected. Regression results shows that the model explains 80 percent of the variation in the dependent variable and the co-efficient sign for the direct foreign investment (FDI) is positive of what was expected. The value of $\mathrm{R}^{2}$ and adjusted $\mathrm{R}^{2}$ are somewhat quite high (0.8393) and Durbin Watson stat is 1.712 not very close to 2 but somehow indicate that there is no problem of autocorrelation. Regression results show that an increase in FDI will result in an increase of .694 in Stock market Development. The results implies that the Foreign direct investment have a positive impact over Stock Market Development. With Domestic Savings (Sav), the results show that with an increase in Domestic savings the Stock Market Development (SMD) increases by 1.356. The results show Domestic Savings has a positive impact over SMD and this result is in accordance to previous theories. The Exchange rate result shows that with an increase in the exchange rate means depreciation in the currency then there will be a negative impact over the SMD by 1.172403. The negative impact of exchange rate over Stock market Development is same that we have expected from previous literature. As the Dimitrova (2005) found that, the depreciation in currency of a country will result in depressing the Stock Market of that country. Lastly the inflation rate shows insignificant results meaning that inflation have no significant impact over stock market development and this result somehow was expected in our study because our host country is a high inflation country as the Boyd, Levine, \& Smith (1996 and 2001) argued that for a high inflation countries (where average inflation rate is above 15 percent) when there is an additional increase in inflation above that edge then the marginal impact of inflation on stock market development decreases rapidly. In addition, Ghazouani (2004) study results showing insignificance between changing inflation and stock market development.

\section{Conclusion}

The purpose of this study is to analyze the role of FDI in stock market development of a lower middle-income developing country like Pakistan. The aim behind conducting this study was also to determine whether these two important variables are related or not in Pakistan because every country has its own local dynamics. Some other important variables domestic savings, exchange rate and inflation have also been incorporated in this study along with our main independent variable FDI. By using annual time series data from 1988 to 2009 and by applying ordinary least square (OLS) we find positive significant impact of FDI on Stock market development in Pakistan. With one percent increase in FDI, this will result in approx. 70\% increase in stock market development. While discussing other variables, domestic savings can have a positive significant impact, exchange rate can have a negative significant impact and while inflation can have an insignificant impact over stock market development. These results are according to our expectations.

Government policy makers to develop policies that make a friendly business environment and where investors feel relaxed with legal and financial framework of the country can use the findings of this study. First measure is the assurance of political stability in the country. The government of Pakistan must pass a law that protects foreign investor's interest and assets from changing government policies. High quality infrastructure availability can also enhance FDI inflows in the country. Savings behavior must be encouraged in the country through appropriate savings policy from the government. When there is a foreign investment in the country then more jobs are available for people so people can have more spare money from jobs for savings. The government must made efforts to control volatility in exchange rate and inflation rate through effective monitory policy measures. Political stability must be the first and foremost priority by the government of Pakistan if they want to achieve above-mentioned objectives. The results of this study cannot be generalized to all developing countries because all countries have their own local changing aspects. Furthermore, in future the researchers can modify the model in various contexts as per their research requirements. 


\section{References}

Adam, M. A. \& Tweneboah, G. (2009). Foreign Direct Investment and Stock Market Development: Ghana's Evidence. International Research Journal of Finance and Economics, 26, 178-185.

Adjasi, C. K. D. \& Biekpe, B. N. (2005). Stock Market Returns and Exchange Rate Dynamics in Selected African Countries: A bivariate analysis. The African Finance Journal, South Africa.

Agarwal, S. (2001). Stock Market Development and Economic Growth: Preliminary Evidence from African Countries. Journal of Sustainable Development in Africa, 3(1), 48-56.

Alfaro, L. (2003). Foreign Direct Investment and Growth: Does the Sector Matter? Harvard Business School.

Alfaro, L., Chanda, A., Ozcan, K. S. \& Sayek, S. (2004). FDI and Economic Growth: The Role of Local Financial Markets. Journal of International Economics, 64(1), 89-112.

Ayanwale, B. A. (2007). FDI and Economic Growth: Evidence from Nigeria. African Economic Research Consortium, Paper 165.

Baker, M., Foley, F. C. \& Wurgler, J. (2004). The Stock Market and Investment: Evidence from FDI Flows. The National Bureau of Economic Research, Working paper 10559.

Boyd, H. J., Levine, R. \& Smith, D. B. (1996). Inflation and Financial Market Performance. Federal Reserve Bank of Minneapolis Research Department, Working paper 573D.

Boyd, H. J., Levine, R. \& Smith, D. B. (2001). The Impact of Inflation on Financial Sector Performance. Journal of Monetary Economics, 4, 221-248.

Brasoveanu, O. L., Dragota, V., Catarama, D. \& Semenescu, A. (2008). Correlations Between Capital Market Development and Economic Growth: The Case Of Romania.

Carkovic, M \& Levine, R. (2002). Does Foreign Direct Investment Accelerate Economic Growth? Department of Finance Working paper, University of Minnesota.

Claessens, S., Klingebiel, D. \& Schmukler, L. S. (2001). FDI and Stock Market Development: Complements or Substitutes? Joint Conference of the IDB and the World Bank: The FDI Race: Who Gets the Prize? Is it Worth the Effort?

Dimitrova, D. (2005). The Relationship between Exchange Rates and Stock Prices: Studied in a Multivariate Model. Issues in political Economy, 14, 1-25.

Franck, P. \& Young, A. (1972). Stock price Reaction of Multinational Firms to Exchange Realignments. Financial Management, 1(3), 66-73.

Garcia, F. V. \& Liu, L. (1999). Macroeconomic Determinants of Stock Market Development. Journal of Applied Economics, 2(1), 29-59.

Ghazouani, S. (2004). Does inflation affect financial performance in the MENA region? Review of Middle East Economics and Finance, 3(4), DOI: 10.2202/1475-3693.1044

Gilani, J. U., Nawaz, M. M. \& Nazir, S. M. (2010). Relationship between economic growth and stock market development. African Journal of Business Management, 4(16), 3473-3479.

Halalmeh, A. M. \& Sayah, M. A. (2010). Impact of foreign Direct Investment on Shares Market Value in Amman Exchange Market. American Journal of Economics and Business Administration, 2 (1), 35-38.

Johnson, A. (2005). The Effects of FDI Inflows on Host Country Economic Growth, Working paper No. 58, Centre for Excellence for Science and Innovation Studies, Royal Institute of Technology. Journal of Applied Quantitative Methods, 3(1), 64-75.

Kalim, R. \& Shahbaz, M. (2009). Impact of Foreign Direct Investment on Stock Market Development: The Case of Pakistan. Global Conference on Business and Economics, ISBN 978-0-9742114-2-7

Mohtadi, H. \& Agarwal, S. (2001). Stock Market Development and Economic Growth: Evidence from Developing Countries.

Muhammad, N. \& Rasheed, A. (2002). Stock Prices and Exchange Rates: Are they related? Evidence from South Asian Countries. The Pakistan Development Review, 41(4), 535-550.

Naceur, B. S., Ghazouani, S. \& Omran, M. (2007). The determinants of stock market development in the Middle-Eastern and North African region. Emerald Managerial Finance, 33(7), 477-499. DOI 10.1108/03074350710753753.

Nieuwerburgh, V. S., Buelens, F. \& Cuyvers, L. (2005). Stock Market Development and Economic Growth in Belgium. Working Paper Url:http://www.uwm.edu/ mohtadi/PA1-4-01.pdf

Parsva, P. \& Lean, H. H. (2011). The Analysis of Relationship between Stock Prices and Exchange Rates: Evidence from Six Middle Eastern Financial Markets. International Research Journal of Finance and Economics, 66, 157-171. 
Rahman, M. M. \& Salahuddin, M. (2009). The determinants of economic growth in Pakistan: Does stock market development play a major role? 38th Australian Conference of Economists (ACE 2009), 28-30 Sept 2009, Adelaide, Australia.

Saibu, O. M., Wosa, P. \& Agbeluyi, M. A. (2011). Financial Development, Foreign Direct Investment and Economic Growth in Nigeria. Journal of Emerging Trends in Economics and Management Sciences, 2 (2), 146-154.

Shahbaz, M., Ahmed, N. \&Ali, L. (2008). Stock Market Development and economic Growth: ARDL Causality in Pakistan. International Research Journal of Finance and economics, 14, 184-194.

Singh, A. (1997) Financial Liberalization, Stock Markets, and Economic Development. The Economic Journal, 107(442), 771-782.

Subair, K. \& Salihu, M. O. (2010). Exchange Rate Volatility and the Stock Market: The Nigerian Experience.

Tabak, M. B. (2006). The Dynamic Relationship between Stock Prices and Exchange Rates: evidence for Brazil. International Journal of Theoretical and Applied Finance, 9(8), 1377-1396.

Torre, L. D. A., Gozzi, C. J. \& Schmukler, L. S. (2006). Stock Market Development Globalization: Whether the Gains from Reforms?

Yartey, A. C. (2008). The Determinants of Stock Market Development in Emerging Economies: Is South Africa Different. IMF Working Paper, WP/08/32. 